UDC 338.45.01

JEL Classification: C51

Myachin V.G.

\title{
FUZZY-LOGICAL APPROACH TO STRATEGIC PLANNING OF INVESTMENT AND INNOVATION ACTIVITY OF ENTERPRISES
}

\author{
Ukrainian State University of Chemical Technology, Dnipro, Ukraine
}

\begin{abstract}
The article shows that almost all modern enterprises currently in their economic activities are faced with the need for strategic planning. The importance of strategic planning is especially important for enterprises that show investment and innovation activity. The classic SWOT analysis (Strength, Weakness, Opportunity, Threats) is one of the simple practical methods used to study various types of risks, strategic forecasting of the development of enterprises, regions and economic sectors. At the same time, the use of SWOT analysis in its classical form is not sufficiently acceptable and effective. The author proposes to use a fuzzy-logical approach and the theory of fuzzy sets for a more adequate presentation and evaluation of the results of the SWOT analysis. An algorithm for fuzzy SWOT analysis is proposed, the choice of membership functions and the range of their definition are justified. The key internal and external factors are given, the consideration of which allows you to choose the most effective strategy of an innovative enterprise. Further research involving the ranking of strategies will also allow us to construct a model of an optimal portfolio of strategies.
\end{abstract}

Keywords: fuzzy SWOT analysis, fuzzy classification; management tools; risk forecasting; fuzzy modeling, strategic planning.

DOI: $10.32434 / 2415-3974-2018-8-2-21-25$

\section{Formulation of problem}

Strategy formulation is the process of developing long-term goals for an effective management of environmental factors. The ever severe dynamic competitive environment has led to increasing complexity of strategic decision making in giant organizations. Strategy formulation is one of basic processes in achieving long range goals. The use of SWOT analysis in its classical form is not sufficiently acceptable and effective. Therefore, there was a need to use a fuzzy-logical approach and the theory of fuzzy sets for a more adequate presentation and evaluation of the results of the SWOT-analysis.

Analysis of last researches and publications

Recently a number of publications describing the use SWOT analysis with elements of fuzzy logic and fuzzy sets (Zumstein D. (2007) [1], Taghavifard M.T., Mahdiraj H.A, Alibakhshi A.M., Zavadskas E.K. and Bausys R. (2013) [2]). Fuzzy SWOT analysis can be successfully used to assess and analyze all sorts of project management tasks (investment, innovation, development, design and market launch of products, etc.) (Chernov V., Dorokhov O., Dorokhova L. (2016) [3]).
Setting objectives and the purpose of the study

The notion of fuzzy theory has been applied in strategic planning, but to our information, it seems that there is a high scope for application of fuzzy sets in SWOT matrix. In this article an algorithm is presented for rectifying the deficiency and problems of the fuzzy SWOT matrix through the use of fuzzy sets. Also the focus of this paper is to construct a model of an optimal portfolio of strategies of innovative enterprises.

Presentation of the main material of research

SWOT analysis is the most frequently used method of strategic analysis and planning in the theory and practice of strategic management. Until now, in most cases, SWOT analysis is applied in the following way: elements or attributes in SWOT are classified sharply, that is, an attribute is classified precisely and only for one area (Strength, Weakness, Opportunity or Threats in Fig. 1).

In fact, in SWOT dominates a «negative-orpositive» and a «internal-or-external-thinking». However, it is often inadequate to classify objects sharply, as Fig. 2 shows: although element 1 and 2 are located nearly at the same position, they sharply

(C) Myachin V.G., 2018 


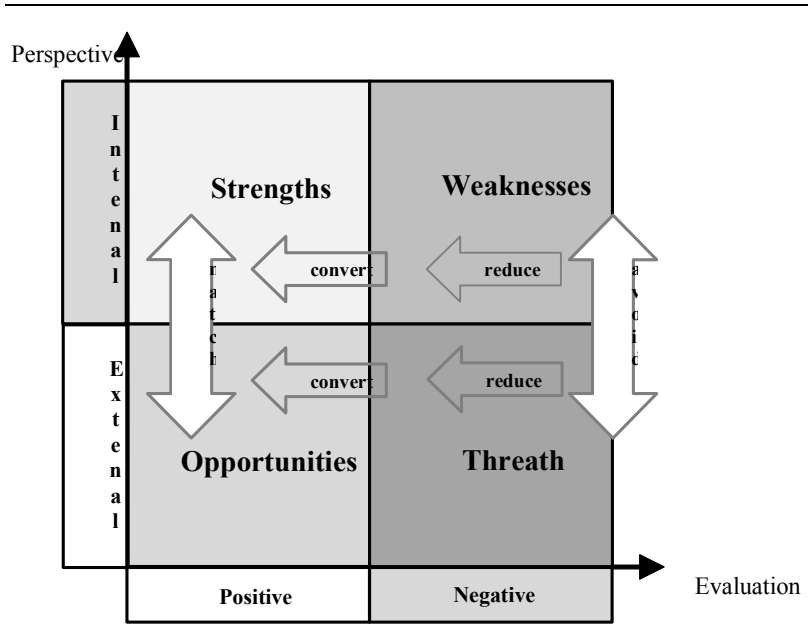

Fig. 1. Sharp SWOT matrix

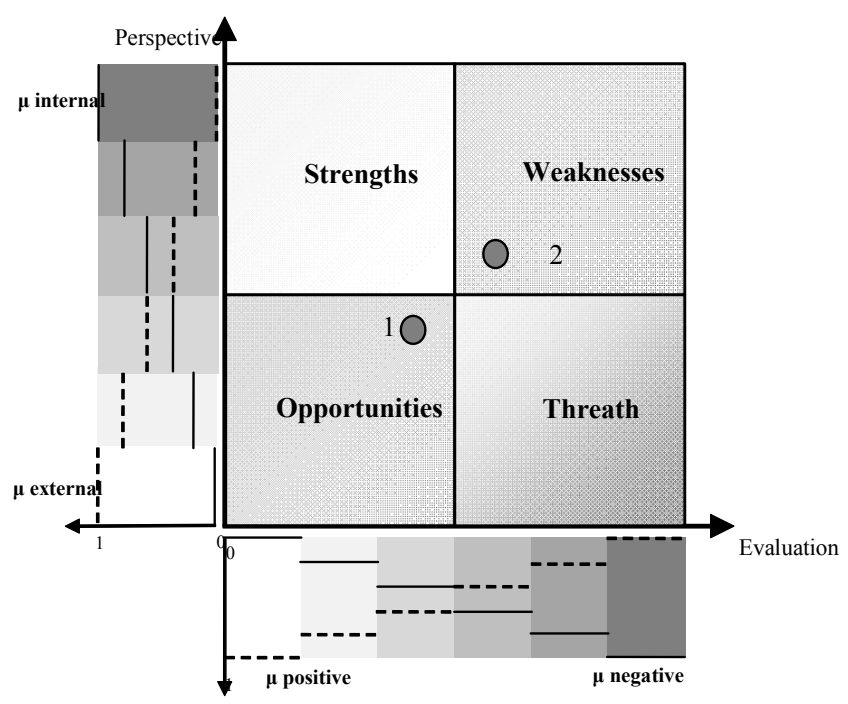

Fig. 2. Fuzzy SWOT matrix

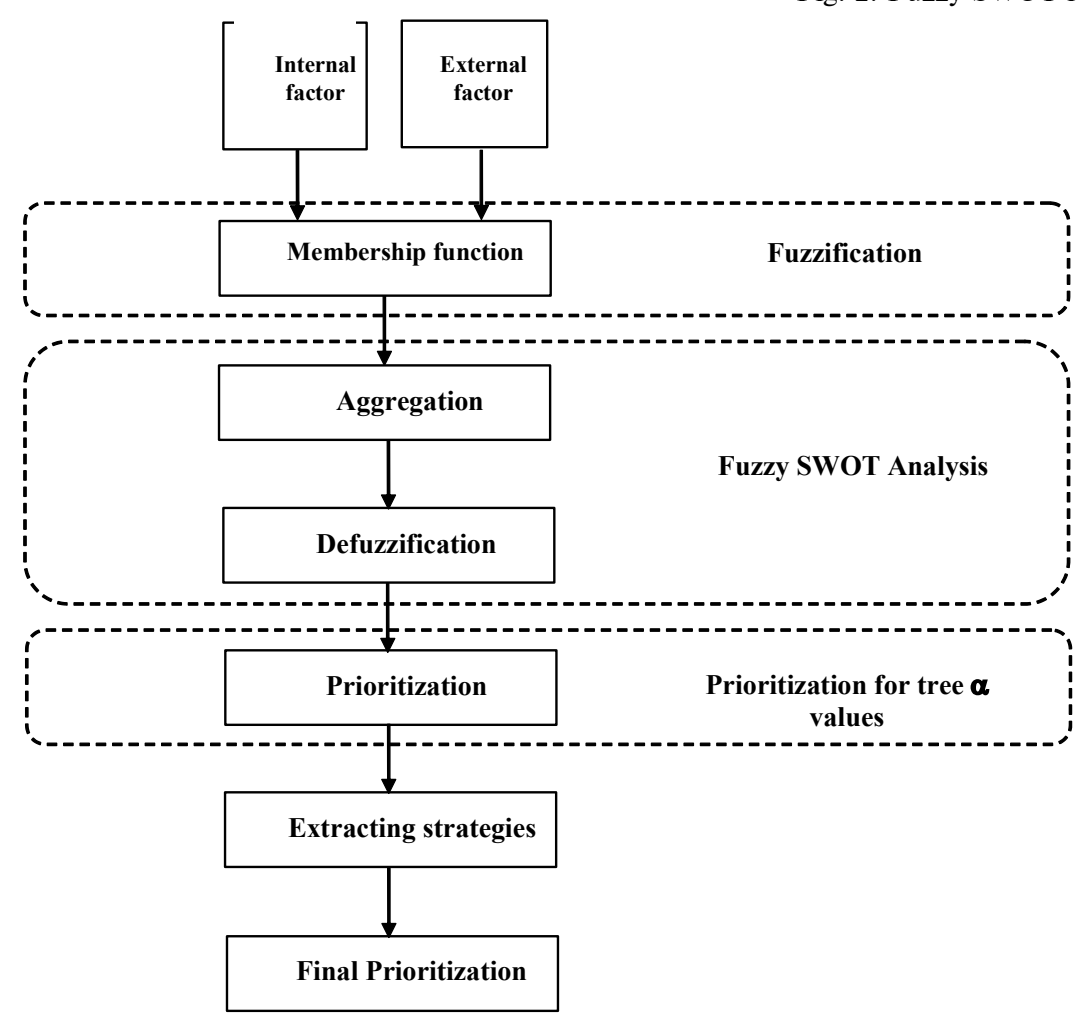

Fig. 3. The general scheme of the algorithm of the proposed fuzzy SWOT analysis

belong to different, opposite classes: element 2 is internal and negative, element 1 is external and positive.

As this example point out: it makes sense to consider transitions between different classes step like. With a fuzzy SWOT analysis (Fig. 2), the classification problem can be avoided, since the classified elements can be partly internal, external, positive and negative at the same time.

Algorithm of the proposed fuzzy SWOT analysis consists of six standard stages as follows (in Fig. 3):

- membership function;
- aggregation;

- defuzzibcation;

- prioritization;

- extracting strategies;

- final prioritization.

There are more than a dozen typical forms of curves to define membership functions of fuzzy sets: triangular, trapezoidal, Gaussian, bell-shaped, sigmoidal, double sigmoidal, the product of two sigmoidal functions, $\mathrm{z}$-functions, s-functions and their generalizations. At present, however, in fuzzy modeling systems due to the logical transparency 

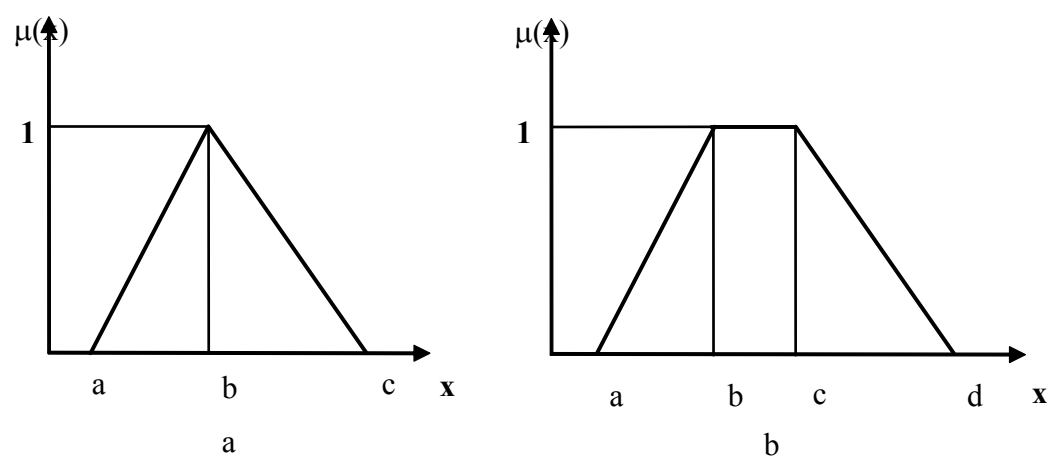

Fig. 4. Triangular (a) and trapezoidal (b) forms of membership functions of fuzzy sets

and the possibility of obtaining the output results with the required accuracy, the most widespread are the triangular and trapezoidal forms of membership functions (Fig. 4).

These forms of membership functions can be used to formalize fuzzy gradations of input parameters in rules.

The triangular membership function is uniquely defined by three parameters $(a, b, c)$, where $a$ is the left base of the membership function, $b$ is the center of the membership function, and $\mathrm{C}$ is the right base of the membership function. Its value at $\mathrm{x}$ is calculated as follows (Fig. 4,a):

$$
\begin{gathered}
\mu(x)=0, x \leq a ; \\
\mu(x)=(x-a) /(b-a), a \leq x \leq b ; \\
\mu(x)=(c-x) /(c-b), b \leq x \leq c ; \\
\mu(x)=0, x \geq a .
\end{gathered}
$$

For $(b-a)=(c-b)$ we have the case of the symmetric triangular membership function.

For the trapezoidal membership function, it is necessary to set the values of its four parameters (a, $b, c, d)$, where a is the left base of the membership function, $b$ is the left border of the mode, $c$ is the right border of the mode, $d$ is the right base of the membership function. The value of this membership function at point $\mathrm{x}$ is calculated according to the expression (Fig. 4,b):

$$
\begin{gathered}
\mu(x)=0, x \leq a ; \\
\mu(x)=(x-a) /(b-a), a \leq x \leq b ; \\
\mu(x)=1, b \leq x \leq c ; \\
\mu(x)=(d-x) /(d-c), c \leq x \leq d ; \\
\mu(x)=0, x \geq d .
\end{gathered}
$$

For $(b-a)=(d-c)$ the trapezoidal membership function takes on a symmetrical appearance.
The type of membership function is optional but to simplify the computation of the area location in next stages, we suggest the triangular membership functions. A "triangular membership functions" can be specibed by three parameters $\left(\mathrm{x}^{\mathrm{p}}, \mathrm{X}^{\mathrm{m}}, \mathrm{X}^{\mathrm{o}}\right)$ as follows [4]:

$$
\mathrm{y}=\operatorname{triangle}\left(\mathrm{x} ; \mathrm{x}^{\mathrm{p}} ; \mathrm{x}^{\mathrm{m}} ; \mathrm{x}^{\mathrm{o}}\right) \text {, }
$$

where in this paper, $\mathrm{x}^{\mathrm{p}}, \mathrm{x}^{\mathrm{m}}$ and $\mathrm{x}^{\mathrm{o}}$ are called pessimistic, probable and optimistic values respectively.

For each internal factor a suitable membership function is developed in the range -10 to 10 . As each factor may exhibit two sided meaning, therefore the negative part shows the weakness and the positive part of the fuzzy membership function signibses the strength of the factor.

As we know, to describe complex objects requires a large number of parameters-usually dozens of parameters in the case of economic objects. For complex economic objects there is a need to split them into subsystems, each of which has fewer parameters forming the «input-output» groups. The set of such groups of parameters fully describes the complex object chosen for the study.

When grouping parameters, it is important that the input parameters are not interrelated. On the contrary, if such parameters are used in the study, then their impact on the state of the object can be overestimated. It follows that for each group of parameters it is advisable, firstly, to rank the input parameters by the degree of their influence on the target parameter, and, secondly, to evaluate the mutual influence of the input parameters in one group.

To solve this problem, it is possible to use an expert method, but with the lack of information it is advisable to involve correlation analysis, which allows to identify statistically significant relationships between the parameters.

To simplify the interpretation of the value of the correlation value of each correlation coefficient is associated with a corresponding linguistic value of the coupling strength between the according to Table 1 . 
Table 1

Linguistic description of the strength of the connection between the input parameters based on the correlation coefficient

\begin{tabular}{c|c}
\hline $\begin{array}{c}\text { Numerical value of the } \\
\text { correlation coefficient }\end{array}$ & Binding force $\mathrm{a}_{\mathrm{kj}}$ \\
\hline $\mathrm{r}_{\mathrm{kj}}$ & almost absent \\
\hline $0 \leq\left|\mathrm{r}_{\mathrm{kj}}\right|<0,2$ & very weak \\
\hline $0,2 \leq\left|\mathrm{r}_{\mathrm{kj}}\right|<0,3$ & weak \\
\hline $0,3 \leq\left|\mathrm{r}_{\mathrm{kj}}\right|<0,5$ & moderate \\
\hline $0,5 \leq\left|\mathrm{r}_{\mathrm{kj}}\right|<0,7$ & average \\
\hline $0,7 \leq\left|\mathrm{r}_{\mathrm{kj}}\right|<1,0$ & strong \\
\hline
\end{tabular}

At the next stage of the study, a table of parameters connectivity is formed (Table 2), on the basis of which the expert additionally analyzes the input parameters. In Table $2 \mathrm{p}_{1}, \mathrm{p}_{2}, \ldots, \mathrm{p}_{\mathrm{m}}-$ characteristic, $\mathrm{p}_{\mathrm{t} 1}, \mathrm{p}_{\mathrm{t} 2}, \ldots, \mathrm{p}_{\mathrm{tm}}-$ target parameter.

Table 2

Table of connectivity options

\begin{tabular}{c|c|c|c|c}
\hline $\mathrm{p}_{\mathrm{t} 1}$ & $\mathrm{p}_{\mathrm{t} 2}$ & $\ldots$ & $\mathrm{p}_{\mathrm{tm}}$ & \\
\hline $\mathrm{p}_{1}$ & $\mathrm{a}_{11}$ & $\mathrm{a}_{12}$ & $\ldots$ & $\mathrm{a}_{1 \mathrm{~m}}$ \\
\hline $\mathrm{p}_{2}$ & $\mathrm{a}_{21}$ & $\mathrm{a}_{22}$ & $\ldots$ & $\mathrm{a}_{2 \mathrm{~m}}$ \\
\hline$\ldots$ & $\ldots$ & $\ldots$ & $\ldots$ & $\ldots$ \\
\hline $\mathrm{p}_{\mathrm{N}}$ & $\mathrm{a}_{\mathrm{N} 1}$ & $\mathrm{a}_{\mathrm{N} 2}$ & $\ldots$ & $\mathrm{a}_{\mathrm{Nm}}$ \\
\hline
\end{tabular}

To extract strategies on the basis of internal and external factors, it is necessary to aggregate the membership functions of the factors at aggregation stage. In this regard, we deыne a three dimensional surface based on the membership functions of internal and external factors. This is applicable using a suitable t-norm such as min operator. Each point of this surface in SWOT matrix is derived from the intersection of membership functions of relative external and internal factors i.e.:

$$
\mu_{\mathrm{S}}(\mathrm{x}, \mathrm{y})=\min \left\{\mu_{\mathrm{I}}(\mathrm{x}), \mu_{\mathrm{E}}(\mathrm{y})\right\}
$$

where $\mu_{\mathrm{s}}(\mathrm{x}, \mathrm{y})$ is the membership function of fuzzy SWOT matrix and $\mu_{\mathrm{I}}(\mathrm{x})$ and $\mu_{\mathrm{E}}(\mathrm{y})$ are the member ship function for internal and external factors respectively.

As input internal factors for SWOT analysis it is offered to choose [1,2]: great and effective relationship, great team work culture, great liquidity, delay in product designing, employees low level motivation, insufficient publicity, imperfective processes, inexperienced managers, imperfective planning, human resource shortcomings, human resource shortcomings in required technologies, job stress, imperfective organizing, low creativity and innovation.

As input external factors for SWOT analysis it is offered to choose [1,2]: upper hand organization support, cooperator companies, probtable market, supply exclusivity, customers' dissatisfaction, universities' capabilities in product designing, employee's low paid salary, high price of product, threats increasing in IT beld.

In defuzzification stage, three 6 -cut surfaces parallel to SWOT matrix plane are defined for cutting the aggregated surface resulted in previous stage. The value of each of the three surfaces is between 0 and 1 and depends on experience of strategist.

Prioritization is done based on $\mathrm{cc}_{\mathrm{j}}$ value, each fuzzy area with greater $\mathrm{cc}_{\mathrm{j}}$ has higher priority.

Every fuzzy area is the aggregation result of two internal and external factors and can result in strategy if the two factors are related together. Extracted strategy should be based on SWOT matrix quadrant. If the fuzzy area is two or four quadrant, the extracted strategy should be based on quadrant including greater part of the fuzzy area, if extracting strategy is not possible, strategy should be based on the smaller part of fuzzy area.

Extracted strategies can be [1,2]: monopolizing the designing and supplying products, mobile based products and services development, out sourcing design of products to universities, assigning the company as exclusive reference of designing and supplying the products, acquiring small and hi-tech companies, redesigning processes to improve company agility, out sourcing designing and producing to small companies, changing current organizational structure to horizontal structure, instituting suppliers evaluation system, instituting innovation and creativity framework, changing aftersale services structure to improve speed and quality of services, holding management skills instruction courses for managers, holding annual fairs, improving employees' salary structure, Improving employees' welfare measures, employing elites with required probciency.

At final prioritization stage, the aforementioned stages are performed and analyzed for three $\sigma$ value. Consequently, the score of strategies with three $\alpha$ values is resulted. The priority of any strategy varies according to $\sigma$ value. In this stage, the weighted average for all strategies is calculated as

$$
\mathrm{r}_{\alpha}=\mathrm{S} \alpha_{\mathrm{i}} \times \mathrm{p}_{\mathrm{i}},
$$

where $\alpha_{i}$ is specibed by strategist and $p_{i}$ is priority of each strategy depending on $\alpha_{i}$ values. Final prioritization is based on $r_{\alpha}$ value. Strategy with smaller $r_{\alpha}$ value has higher priority.

\section{research}

Conclusions and recommendations for further

In this article some of the weaknesses of the SWOT matrix are pointed out and efforts were made 
to solve them using the fuzzy evaluations. The major approach of the presented algorithm was that in most cases the internal and external factors can not be fully recognized as positive or negative, because their impact on the organization could be observed within a wide spread which may include both positive and negative effects.

On the other case, the aggregation of internal and external factors which leads to extract a strategy in a usual matrix would depend on the intensity and inbuence of the factors in proposed algorithm. However, these fuzzy membership functions and the extracted strategies can be well prioritized and it may be possible to concentrate upon strategies with higher priority in implementation stage.

Fuzzy theory can convert quantitative to membership function in addition to qualitative factors and has recognized methods for this propose. Amount of necessary calculations is almost high like most of other fuzzy techniques. Selecting pair of factors that lead to meaningful strategies is difbcult and need experience.

\section{REFERENCES}

1. Zumstein D. Customer performance measurement. Analysis of the Benefit of a Fuzzy Classification Approach in Customer Relationship Management / Darius Zumstein. - Master Thesis, University of Fribourg, Switzerland. - 2007. - 144 p.

2. Taghavifard M.T. An Extension of Fuzzy SWOT Analysis: An Application to Information Technology / Mohammad Taghi Taghavifard, Hannan Amoozad Mahdiraj, Amir Massoud Alibakhshi, Edmundas Kazimieras Zavadskas, Romualdas Bausys. MDPI, Basel, Switzerland. - 2018. - 24 February 2018.

3. Chernov V. Fuzzy logic approach to SWOT analysis for economics tasks and example of its computer realization / Vladimir Chernov, Oleksandr Dorokhov, Liudmyla Dorokhova // Bulletin of the Transilvania University of Bra€ov Series V: Economic Sciences. - Vol. 9 (58). - No. 1. - 2016. - PP. 317-326.

4. Mahmoudi Vahid. Investigation of qualified strategy from SWOT analysis using fuzzy group decision-making techniques in the appliance industry / Vahid Mahmoudi, Mehrdad Hosseini Shakib, Mohsen Mohammadi // Researcher. - 2013. - 5(10). PP. 33-45.

5. Karimi M. An application of fuzzy-logic and greyrelational ANP-based SWOT in the ceramic and tile industry / Marziyeh Karimi, Amir Hossein Niknamfar, Seyed Taghi Akhavan Niaki. - Knowledge-Based Systems. - September 2018. - 33 p.

6. Partani T. Using Fuzzy Analytic Network Process (FANP) in a SWOT Analysis / T. Partani, S.V. Marashi, M. Haji Alishahi // Global Journal of Computer Science and Technology Interdisciplinary. - Volume 13. - Issue 2. - Version 1.0. - 2013. - PP. 16-32.

\section{НЕЧІТКО-ЛОГІЧНИЙ ПІДХІД ДО СТРАТЕГІЧНОГО ПЛАНУВАННЯ ІНВЕСТИЦИЙНОЇ ТА ІННОВАЦІЙНОЇ АКТИВНОСТІ ПІДПРИЕМСТВ}

\section{М'ячин В.Г.}

У статті показано, що практично всі сучасні підприємства в даний час в своїй економічній діяльності стикаються з необхідністю стратегічного планування. Значення стратегічного планування особливо актуально для підприємств, які проявляють інвестиційну та інноваційну активність. Класичний SWOT аналіз (Strength, Weakness, Opportunity, Threats) є одним з простих практичних методів, який використовується для вивчення різних видів ризиків, стратегічного прогнозування розвитку підприємств, регіонів і економічних секторів. У той же час використання SWOT аналізу в його класичній чіткій формі є недостатньо прийнятним і ефективним. Автор пропонує використовувати нечітко-логічний підхід і теорію нечітких множин для більш адекватного уявлення і оцінювання результатів SWOT аналізу. Запропоновано алгоритм нечіткого SWOT аналізу, обгрунтований вибір функцій належності і діапазон областей їх визначення. Наведено ключові внутрішні та зовнішні чинники, облік яких дозволяє вибрати найбільш ефективну стратегію інноваційного підприємства. Подальші дослідження із залученням ранжування стратегій дозволять також побудувати модель оптимального портфеля стратегій інноваційних підприємств.

Ключові слова: нечіткий SWOT аналіз; нечітка класифікація; інструменти управління; прогнозування ризиків; нечітке моделювання; стратегічне планування.

\section{НЕЧЁТКО-ЛОГИЧЕСКИЙ ПОДХОД К СТРАТЕГИЧЕСКОМУ ПЛАНИРОВАНИЮ ИНВЕСТИЦИОННОЙ И ИННОВАЦИОННОЙ АКТИВНОСТИ ПРЕДПРИЯТИЙ}

\section{Мячин В.Г.}

В статье показано, что практически все современные предприятия в настоящее время в своей экономической деятельности сталкиваются с необходимостью стратегического планирования. Значение стратегического планирования особенно актуально для предприятий, которые проявляют инвестиционную и инновационную активность. Классический SWOT-анализ (Strength, Weakness, Opportunity, Threats) является одним из простых практических методов, который используется для изучения различных видов рисков, стратегического прогнозирования развития предприятий, регионов и экономических секторов. В то же время использование SWOT анализа в его классической форме является недостаточно приемлемым и эффективным. Автор предлагает использовать нечётко-логический подход и теорию нечётких множеств для более адекватного представления и оценки результатов SWOT анализа. Предложен алгоритм нечёткого SWOT анализа, обоснован выбор функций принадлежности и диапазон области их определения. Приведены ключевые внутренние и внешние факторы, учёт которых позволяет выбрать наиболее эффективную стратегию инновационного предприятия. Дальнейшие исследования с привлечением ранжирования стратегий позволят также построить модель оптимального портфеля стратегий инновационных предприятий.

Ключевые слова: нечёткий SWOT анализ; нечёткая классификация; инструменты управления; прогнозирование рисков; нечёткое моделирование; стратегическое планирование. 